\title{
Використання металургійних шлаків в якості сорбентів поверхнево-активних речовин
}

\author{
І.В. Грайворонська ${ }^{1}$, Е.Б. Хоботова ${ }^{2}$, М.М. Кірієнко ${ }^{3}$ \\ 1, 2 Харківський національний автомобільно-дорожній університет, (м. Харків, Україна) \\ email: ${ }^{1}$ inna_gra@ukr.net; ${ }^{2}$ elinahobotova@gmail.com. \\ ${ }^{3}$ Харківський національний технічний університет сільського господарства \\ ім. Петра Василенка, (м. Харків, Україна), email: hfinpomt@ukr.net
}

\begin{abstract}
Визначено елементний, оксидний, мінералогічний та радіонуклідний склад металургійних шлаків. Встановлено клас радіаційної небезпеки досліджених шлаків. Визначено питомі поверхні шлакових сорбентів. Теоретично і експериментально обґрунтовані принципи визначення сорбційної активності металургійних шлаків. Показана можливість використання шлаків з основним мінералом діопсидом в якості сорбентів для очищення води. Активність сорбції шлаку обумовлена високим вмістом діопсид в аморфному стані. Показана можливість сорбції шлаком органічних речовин. За хімічним складом і радіаційними характеристиками шлак може бути використаний в якості технічного матеріалу. Показано прояв сорбційної активності металургійного шлаку. Сорбційні властивості обумовлені наявністю аморфного стану речовини. Визначено можливість використання шлаків при сорбційній обробці вод в технологічних циклах. Для очищення стічних вод від поверхнево-активних речовин на рівні високих концентрацій запропонована раціональна протиточно-ступінчата адсорбційна схема періодичної дії. Представлені ресурсозберігаючі розробки, що дозволяють розширити сировинну базу для виробництва сорбентів, поліпшити екологічну ситуацію регіонів за рахунок запобігання скиду промислових стічних вод при впровадженні систем оборотного водопостачання підприємств.
\end{abstract}

Ключові слова: металургійний шлак, сорбент, адсорбція, мінерал, очистка, стічні води, поверхнево-активні речовини

Постановка проблеми та її актуальність.

Одним із перспективних способів очистки вод $€$ сорбція та сорбційні технології з використанням металургійних шлаків [1]. Економічна доцільність сорбційної очистки підвищується при використанні в якості сорбентів металургійних шлаків різних виробництв: ТОВ Побужського феронікелевого комбінату (ПФНК), ПАТ Нікопольського заводу феросплавів (НЗФ) та ВАТ «АрселорМіттал Кривий Ріг».

Актуально й найбільш перспективне використання сорбційних методів в технологіях глибокої очистки стічних вод від ПАР для виробництва технічної води в замкнених циклах водоспоживання. У зв'язку з цим, очистка вод не може бути здійснена стандартними методами та особливе значення набувають локальні очищувальні установки для стоків з однорідними забруднювачами.

Актуальність теми полягає в покращенні екологічної ситуації промислових регіонів при використанні металургійних шлаків в сорбційних технологіях очистки промислових стічних вод з суттєвою мінімізацією їх об'ємів.

Поверхнево-активні речовини (ПАР) - одні 3 самих розповсюджених забруднювачів стічних вод, що характерні для багатьох галузей промисловості. Створення технологій глибокої очистки стічних вод від ПАР з використанням нових ефективних та економічно вигідних адсорбентів $є$ актуальною задачею. ПАР $€$ міцелоутворюючими речовинами, утворення асоциатів протікає в стічних водах також.

Аналіз результатів останніх досліджень та публікацій, що стосуються проблеми. В літературі маються дані про сорбцію ПАР на активному вугіллі, силікагелях та оксидах різних елементів [2]. Причому, у більшості розглянених випадків іон ПАР та поверхня адсорбенту протилежно заряджені. Практично відсутні дані про адсорбцію аніонних ПАР (АПАР) на оксидних сорбентах кислотного характеру. Незважаючи на значну кількість наукових публікацій, в яких розглядаються варіанти практичної утилізації металургійних шлаків, залишаються недостатньо вивченими сорбційні властивості шлаків та можливості їх використання в якості сорбентів при очистці стічних вод від ПАР, що не дає можливості регулювати процес сорбційної очистки вод. Разом з тим подібні питання виникають при практичній реалізації технологічних процесів очистки стічних вод та водопідготовки у зв'язку з підвищенням умов до екологічної безпеки промислових підприємств. $€$ актуальним емпіричне визначення найефективніших умов адсорбційної очистки стічних вод 
шлаковими сорбентами, встановлення загальних закономірностей, що допомагають підвищити ефрективність технологічного режиму.

\section{Мета і задачі роботи.}

Забезпечення екологічної безпеки шляхом запобігання скиду промислових стічних вод при впровадженні систем оборотного водопостачання підприємств за рахунок використання металургійних шлаків в якості сорбційного матеріалу для поверхнево-активних речовин.

Висока ефективність адсорбційних методів очистки вод при рішенні багатьох екологічних та технічних задач можлива тільки за умови розробки технологій на основі теорії адсорбції.

Матеріали і методи дослідження. Дослідження фізико-хімічних властивостей металургійних шлаків. Вивчення властивостей і модифікації металургійних шлаків потребує комплексного підходу, що включає рентгенофазовий, петрографічний, електронно-мікроскопічний, гамма-спектрометричний аналіз і електронно-зондовий мікроаналіз.

Методом повітропроникності визначені питомі поверхні $(S)$ фракцій шлаків <0,63 мм: шлак НЗФ $S=880 \mathrm{~cm}^{2} / \Gamma$; шлак «АрселорМіттал» $S=1625 \mathrm{~cm}^{2} /$ г. Питома поверхня шлаку ПФНК розрахована по значенню, що відповідає максимуму ізотерми адсорбції: $S=4000 \mathrm{~cm}^{2} / \Gamma$.

Рентгенофазовим аналізом в складі шлаку ПФНК виявлено мінерал діопсид $\mathrm{CaMg}\left(\mathrm{SiO}_{3}\right)_{2}$, шарувата структура якого сприяє до прояву ним сорбційних властивостей.

Зразок, оброблений водою протягом місяця, окрім діопсиду містить кварц, маргарит $\quad \mathrm{Ca}_{0,88} \mathrm{Na}_{0,12} \mathrm{Al}_{2}\left(\mathrm{Si}_{2,12} \mathrm{Al}_{1,88} \mathrm{O}_{10}\right)(\mathrm{OH})_{2}$, альбіт $\mathrm{NaAlSi}_{3} \mathrm{O}_{8}$, ілліт $\mathrm{K}\left(\mathrm{Al}_{4} \mathrm{Si}_{2} \mathrm{O}_{9}(\mathrm{OH})_{3}\right)$. В складі шлаку НЗФ окрім мінералу діопсиду виявлено мінерал - титаніт $\mathrm{Ca}\left(\mathrm{Ti}_{0,818} \mathrm{Al}_{0,182}\right)\left(\mathrm{O}_{0,818} \mathrm{~F}_{0,182}\right)\left(\mathrm{SiO}_{4}\right)$. Основними мінералами шлаку «АрселорМіттал» $\epsilon$ ранкініт $\mathrm{Ca}_{3} \mathrm{Si}_{2} \mathrm{O}_{7}$, окерманіт $\mathrm{Ca}_{2} \mathrm{MgSi}_{2} \mathrm{O}_{7}$ та геленіт $\mathrm{Ca}_{2} \mathrm{Al}(\mathrm{Al}, \mathrm{Si})_{2} \mathrm{O}_{7}$.

Елементні склади гранулометричних фракцій шлаку ПФНК практично ідентичні друг другу та складу шлаку НЗФ виробництва сплавів FeSiMn. В останньому випадку спостерігаються від'ємності за завищеним вмістом S, Mn та F. Результати досліджень наведено в таблиці 1.

Порівняння елементного складу гранульованого (фракція >10 мм) та відвального доменних шлаків «АрселорМіттал» показує, що у відвальному шлаку менше Сa, але присутні Fe і Mn. Аналіз оксидного складу фракції >10 мм гранульованого шлаку показав високий вміст алюмосилікатів кальцію та магнію. Результати досліджень наведено в таблиці 2.
Таблиця 1. Елементний склад зразків шлаку виробництва ПФНК та НЗФ

\begin{tabular}{|c|c|c|c|}
\hline \multirow{3}{*}{$\begin{array}{c}\text { Хімічний еле- } \\
\text { мент }\end{array}$} & \multicolumn{3}{|c|}{ Масова доля елементу, \% } \\
\hline & \multicolumn{2}{|c|}{$\begin{array}{c}\text { Шлак ПФНК, } \\
\text { фрракція }\end{array}$} & \multirow{2}{*}{$\begin{array}{c}\text { Шлак НЗФ, } \\
\text { фрракція } \\
<2,5 \text { мм }\end{array}$} \\
\hline & $>20 \mathrm{MM}$ & $<2,5 \mathrm{MM}$ & \\
\hline $\mathrm{O}$ & 63,94 & 52,60 & 49,98 \\
\hline $\mathrm{Na}$ & 0,57 & 0,00 & 0,66 \\
\hline $\mathrm{Mg}$ & 3,50 & 3,15 & 4,10 \\
\hline $\mathrm{Al}$ & 4,44 & 8,95 & 3,38 \\
\hline $\mathrm{Si}$ & 17,28 & 18,01 & 18,72 \\
\hline$S$ & 0,07 & 0,10 & 0,31 \\
\hline $\mathrm{Cl}$ & 0,06 & - & - \\
\hline $\mathrm{K}$ & 0,18 & 0,24 & 1,54 \\
\hline $\mathrm{Ca}$ & 6,38 & 8,76 & 10,10 \\
\hline $\mathrm{Ti}$ & 0,11 & 0,15 & 0,21 \\
\hline $\mathrm{Cr}$ & 0,23 & 0,65 & - \\
\hline $\mathrm{Mn}$ & 0,19 & 0,40 & 9,10 \\
\hline $\mathrm{Fe}$ & 3,05 & 7,00 & - \\
\hline $\mathrm{F}$ & - & - & 1,89 \\
\hline $\mathrm{P}$ & - & - & - \\
\hline $\mathrm{Sr}$ & - & - & - \\
\hline
\end{tabular}

Таблиця 2. Результати електронно-зондового мікроаналізу зразків гранульованого і відвального доменного шлаку ВАТ «АрселорМіттал Кривий Ріг»

\begin{tabular}{|c|c|c|c|c|c|}
\hline \multirow{4}{*}{ 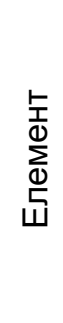 } & \multicolumn{5}{|c|}{$\begin{array}{c}\text { Масова доля елементу (\%) в гранулометричній } \\
\text { фрракції доменного шлаку, мм }\end{array}$} \\
\hline & \multicolumn{4}{|c|}{ гранульованого } & \multirow{3}{*}{$\begin{array}{c}\text { відва- } \\
\text { льного } \\
\text { сере- } \\
\text { дня } \\
\text { проба }\end{array}$} \\
\hline & \multirow{2}{*}{$<0,63$} & \multirow{2}{*}{$\begin{array}{c}1,25- \\
2,5\end{array}$} & \multicolumn{2}{|c|}{$>10$, колір } & \\
\hline & & & білий & сірий & \\
\hline $\mathrm{Si}$ & 12,053 & 15,596 & 5,964 & 12,165 & 7,37 \\
\hline $\mathrm{Ca}$ & 14,683 & 15,535 & 57,770 & 43,834 & 35,42 \\
\hline $\mathrm{Al}$ & 2,051 & 2,289 & 0,731 & 2,385 & 1,01 \\
\hline $\mathrm{Fe}$ & - & - & - & - & 15,38 \\
\hline$S$ & 0,415 & 0,526 & 0,607 & 0,774 & 0,80 \\
\hline $\mathrm{Mg}$ & 2,037 & 3,016 & 1,939 & 3,272 & 1,83 \\
\hline $\mathrm{K}$ & 1,632 & 1,573 & 0,251 & 0,650 & 0,28 \\
\hline $\mathrm{Na}$ & 7,764 & 6,116 & - & - & - \\
\hline $\mathrm{Cl}$ & 20,779 & 13,950 & - & - & - \\
\hline $\mathrm{Mn}$ & 5,795 & 5,439 & - & - & 5,34 \\
\hline $\mathrm{Ti}$ & - & - & - & - & 0,19 \\
\hline $\mathrm{O}$ & 32,790 & 35,959 & 32,742 & 36,924 & 33,10 \\
\hline
\end{tabular}

Доведено, що шлак ПФНК на 53 \% складається з діопсиду в аморфному стані, що підвищує сорбційну активність шлаку за рахунок поверхневого поглинання сорбатів аморфною фазою. 
Розрахунок масової частки вкладу кристалічного (а) і аморфного стану (1 - а) у фракції шлаку $<2,5$ мм проводився за рівнянням:

$$
\mathrm{ax}_{1}+(1-\mathrm{a}) \mathrm{x}_{2}=\mathrm{x}_{3},
$$

де

$$
\mathrm{x}_{1}, \mathrm{x}_{2}, \mathrm{x}_{3} \text { - відповідно масова доля (\%) }
$$

$\mathrm{SiO}_{2}$ в кристалічному, аморфному станах та загальний вміст $\mathrm{SiO}_{2}$ згідно елементному аналізу у фракції шлаку < 2,5 мм. Х 1 - визначається за даними рентгенофазового аналізу (табл. 3); $\mathrm{x}_{2}-$ за даними петрографічного аналізу (табл. 4); $\mathrm{x}_{3}-$ за даними мікрорентгенівського аналізу (табл. 5).

Таблиця 3. Масові долі оксидів елементів згідно результатам

\begin{tabular}{|c|c|c|c|c|c|}
\hline \multirow{2}{*}{ Мінерал } & \multirow{2}{*}{$\begin{array}{l}\text { Масова доля мі- } \\
\text { нералу, \% }\end{array}$} & \multicolumn{4}{|c|}{ Масова доля оксидів, \% } \\
\hline & & $\mathrm{CaO}$ & $\mathrm{MgO}$ & $\mathrm{SiO}_{2}$ & $\mathrm{Al}_{2} \mathrm{O}_{3}$ \\
\hline Діопсид $\mathrm{CaO} \cdot \mathrm{MgO} \cdot 2 \mathrm{SiO}_{2}$ & 92,4 & 24,0 & 17,56 & 51,74 & - \\
\hline Кварц $\mathrm{SiO}_{2}$ & 3,1 & - & - & 3,1 & - \\
\hline Маргарит & 1,8 & - & - & - & - \\
\hline Ілліт $0,5 \mathrm{~K}_{2} \mathrm{O} \cdot 2 \mathrm{Al}_{2} \mathrm{O}_{3} \cdot 2 \mathrm{SiO}_{2} \cdot 1,5 \mathrm{H}_{2} \mathrm{O}$ & 0,9 & - & - & 0,27 & 0,46 \\
\hline Альбіт $0,5 \mathrm{Na}_{2} \mathrm{O} 0,5 \mathrm{Al}_{2} \mathrm{O}_{3} \cdot 3 \mathrm{SiO}_{2}$ & 1,9 & - & - & 1,31 & 0,36 \\
\hline $\begin{array}{l}\text { Сумарний вміст оксидів } \\
\text { за всіма мінералами }\end{array}$ & - & 24,0 & 17,56 & 56,42 & 0,82 \\
\hline
\end{tabular}
рентгенофазового аналізу зразків шлаку ПФНК, оброблених водою

Таблиця 4. Масова доля $\mathrm{SiO} 2$ згідно результатам петрографічного аналізу

\begin{tabular}{|c|c|c|}
\hline Фаза & $\begin{array}{c}\text { Масова доля, } \\
\%\end{array}$ & $\begin{array}{c}\text { Масова доля } \\
\mathrm{SiO}, \%\end{array}$ \\
\hline $\begin{array}{c}\mathrm{Na}_{2} \mathrm{O} \cdot \mathrm{SiO}_{2} \\
\text { склофраза }\end{array}$ & $40-50 \%$ & $\begin{array}{c}19,6-24,5 \\
\text { (середнє 22,0) }\end{array}$ \\
\hline
\end{tabular}

Розрахунок середнього вмісту кристалічного і аморфного стану:

$$
0,5642 a+0,22(1-a)=0,3822 ;
$$

$0,3442 \mathrm{a}=0,1622 ; \mathrm{a}=0,47 ;(1-\mathrm{a})=0,53$.

Крайні значення:

$$
0,5642 a+0,196(1-a)=0,3822
$$$$
0,3682 \mathrm{a}=0,1862 \text {; }
$$

$$
\mathrm{a}=0,506 ; \quad(1-\mathrm{a})=0,494
$$

б)

$$
0,5642 a+0,245(1-a)=0,3822
$$

$$
0,3192 \mathrm{a}=0,1372 \text {; }
$$

$\mathrm{a}=0,429$

$$
(1-a)=0,57
$$

Вміст кристалічного і аморфного станів діопсидового шлаку:

- кристалічний 42,9-50,6\% (середнє 47\%);

- аморфний 49,4-57\% (середнє 53\%).

Таким чином, шлак наполовину складається з діопсиду в аморфному стані, що повністю підтверджує механізм сорбції за рахунок поглинання сорбційно-активною поверхнею шлаку поверхнево-активних речовин.

За допомогою растрової електронної мікроскопії доведено присутність склофази та рідких пор на поверхні зразків шлаків ПФНК та шлаку НЗФ виробництва FeSiMn (рис. 1 a, б). Поверхня відвального шлаку «АрселорМіттал» по зрівнянню з гранульованим більш розрихлена (рис. 1 в, г).

Таблиця 5. Масові долі оксидів елементів згідно елементному аналізу фракції шлаку < 2,5 мм

\begin{tabular}{|c|c|}
\hline Оксид & Масова доля оксиду, \% \\
\hline $\mathrm{CaO}$ & 12,33 \\
\hline $\mathrm{MgO}$ & 5,25 \\
\hline $\mathrm{SiO}_{2}$ & 38,22 \\
\hline $\mathrm{Fe}_{2} \mathrm{O}_{3}$ & 10,00 \\
\hline $\mathrm{Al}_{2} \mathrm{O}_{3}$ & 16,87 \\
\hline
\end{tabular}

Різна величина кристалітів та їх морфологія визначають напругу в шлаковому склі та впливають на сорбційну активність фракції. На мікрофотографріях видна структуроутворююча пористість. Згідно стану поверхневого шару всі вивчені шлаки є хорошими адсорбентами, що мають чисельні мікроскопічні виступи та поглиблення.

Гамма-спектрометричним методом визначені питомі активності радіонуклідів $\left(C_{i}\right)$ та ефрективні питомі активності $\left(C_{\text {eф. }}\right)$ шлаків, які не перевищу- 
ють 370 Бк/кг, що відповідає I класу радіаційної небезпеки. Результати наведено у табл. 6 та 7.

Таблиця 6. Результати гама-спектрометричного аналізу шлаків ПФНК та НЗФ

\begin{tabular}{|c|c|c|c|c|c|}
\hline \multirow{2}{*}{$\begin{array}{c}\text { Фракції } \\
\text { шлаку ви- } \\
\text { робниц- } \\
\text { тва } \\
\text { сплаву }\end{array}$} & \multicolumn{3}{|c|}{$C_{i}$, Бк/кг } & \multirow{2}{*}{$\begin{array}{l}C_{\text {сум. }} \\
\text { Бк/кг }\end{array}$} & \multirow{2}{*}{$\begin{array}{l}\text { Ceф., } \\
\text { Бк/кг }\end{array}$} \\
\hline & ${ }^{40} \mathrm{~K}$ & ${ }^{226} \mathrm{Ra}$ & ${ }^{232} \mathrm{Th}$ & & \\
\hline \multicolumn{6}{|c|}{ ПФНК } \\
\hline FeNi & 112,0 & 63,0 & 36,3 & 211,0 & $\begin{array}{r}120,0 \\
\pm 12,5 \\
\end{array}$ \\
\hline \multicolumn{6}{|c|}{$\mathrm{H} 3 \Phi$} \\
\hline FeSiMn & 670 & 169 & 32,3 & 871,0 & $\begin{array}{r}268 \pm \\
26,2\end{array}$ \\
\hline
\end{tabular}

Таким чином, шлаки можуть використовуватись в якості технічних матеріалів: будівельних матеріалів та сорбентів.

Дослідження сорбційних властивостей металургійних шлаків. Сорбційні властивості

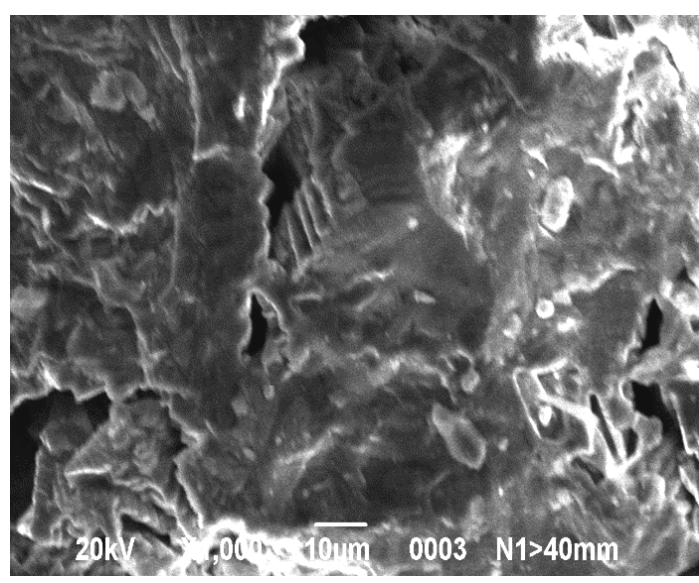

a

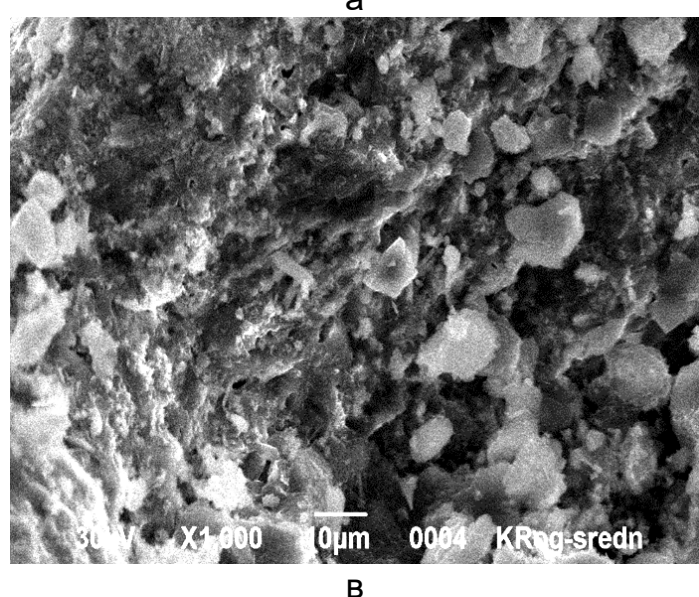

шлаків визначали в статичних та динамічних умовах за зміною концентрацій поглинених речовин (сорбатів) в розчині.

Концентрацію сорбатів АПАР у водних розчинах визначали за допомогою «Методики виконання вимірювань масової концентрації аніонних поверхнево-активних речовин (АПАР) в пробах природної, питної та стічної води» фрлуориметричним методом на аналізаторі рідини «Флюорат02». Методика виконання вимірювань забезпечує отримання результатів з похибкою, що не перевищує значення $\pm 20 \%$ для вірогідності $P=0,95$. Метод засновано на екстракції хлороформом іонних пар АПАР з барвником акридиновим жовтим та вимірювання концентрації АПАР у отриманому екстракті фолуориметричним методом з використанням аналізатора рідини «Флюорат-02».

Пробу води об'ємом $5 \mathrm{~cm}^{3}$ поміщали у розподільну ємність місткістю $50 \mathrm{~cm}^{3}$, добавляли $4 \mathrm{~cm}^{3}$ дистильованої води та контролювали за допомогою універсального індикатору $\mathrm{pH}$, який повинен бути в межах 3-8.

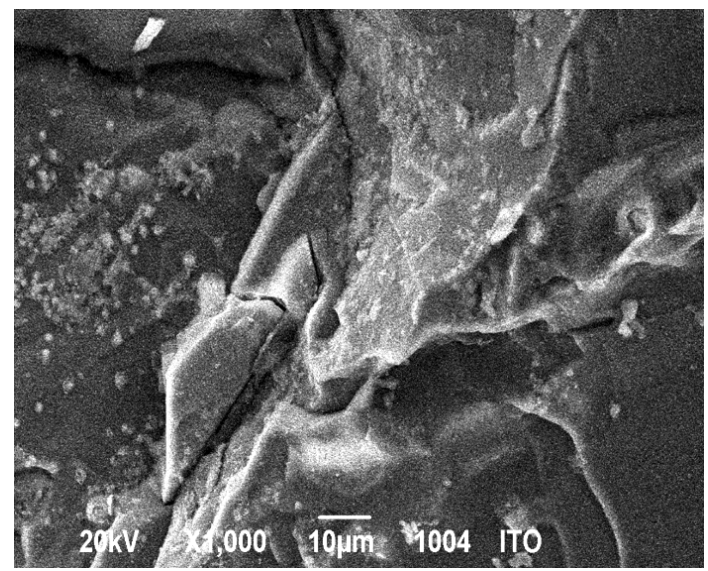

б

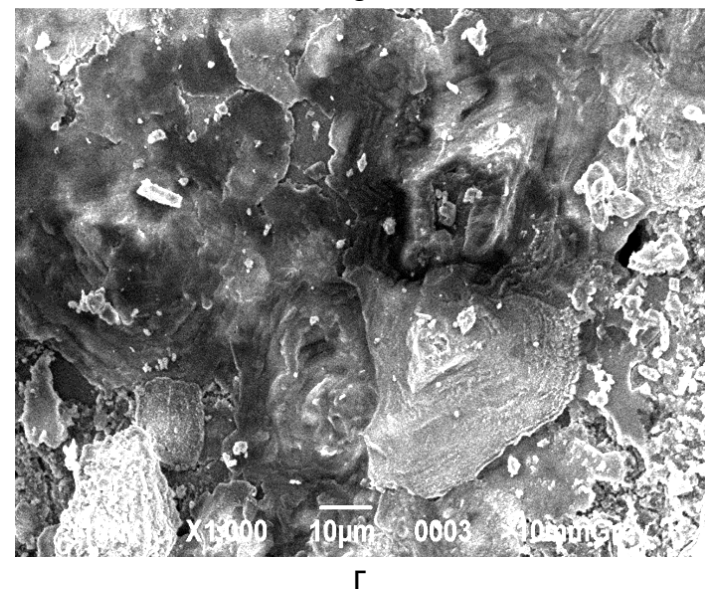

Рис. 1. Мікрофотографії поверхні частинок: а - фракції шлаку >20 мм ПФНК; б - шлаку НЗФ виробництва FeSiMn; в, г - доменного шлаку «АрселорМіттал»: в - відвального, середня проба; г - гранульованого, фракція >10 мм. Збільшення 1000

Інженерія природокористування, 2019, №3(13), с. 110 - 117

Engineering of nature management, 2019, \#3(13), p. $110-117$ 
Таблиця 7. Результати гама-спектрометричного аналізу фракцій доменних шлаків ВАТ «АрселорМіттал Кривий Ріг»

\begin{tabular}{|l|c|c|c|c|}
\hline \multirow{2}{*}{$\begin{array}{c}\text { Гранулометрична } \\
\text { фрракція, мм }\end{array}$} & \multirow{2}{*}{ Сеф., Бк/кг } & \multicolumn{3}{|c|}{$C_{\text {, Бк/кг (\% Ссум. }}$} \\
\cline { 3 - 5 } & & ${ }^{40 К}$ & ${ }^{226} \mathrm{Ra}$ & ${ }^{232} \mathrm{Th}$ \\
\hline \multicolumn{5}{|c|}{ Відвальний доменний шлак } \\
\hline Середня проба & $16,5 \pm 4$ & - & $12,8(82,0)$ & $2,8(18,0)$ \\
\hline \multicolumn{5}{|c|}{ Гранульований доменний шлак } \\
\hline Середня проба & $127 \pm 15$ & $116(51,4)$ & $85,1(37,7)$ & $24,5(10,9)$ \\
\hline$>10$ мм & $117 \pm 17$ & $209(69,5)$ & $67,1(22,4)$ & $24,3(8,1)$ \\
\hline$>10$ мм, колір сірий & $140 \pm 19$ & $354(77,9)$ & $71,3(15,7)$ & $29,2(6,4)$ \\
\hline$>10$ мм, колір білий & $91,4 \pm 13$ & $95,4(55,3)$ & $57,8(33,5)$ & $19,4(11,3)$ \\
\hline $5-10$ мм & $119 \pm 18$ & $244(72,9)$ & $65,4(19,6)$ & $25,1(7,5)$ \\
\hline $2,5-5$ мм & $131 \pm 18$ & $269(72,8)$ & $74,6(20,2)$ & $25,7(7,0)$ \\
\hline $1,25-2,5$ мм & $153 \pm 19$ & $369(76,5)$ & $87,7(18,2)$ & $25,5(5,3)$ \\
\hline $0,63-1,25$ мм & $157 \pm 19$ & $368(75,9)$ & $88,6(18,3)$ & $28,3(5,8)$ \\
\hline$<0,63$ мм & $161 \pm 19$ & $391(76,7)$ & $90,6(17,8)$ & $28,3(5,6)$ \\
\hline
\end{tabular}

Сумарну концентрацію катіоноактивних ПАР (КПАР), що входять до складу препарату Polyram, визначали методом загального вуглецю, що припустимо для суміші речовин з близькими адсорбційними властивостями. Аналізатор загального вуглецю TOC-VCSH/TOC-VCSN призначений для визначення вмісту загального вуглецю, неорганічного вуглецю, загального органічного вуглецю, що не видаляється при продуванні вуглецю, і загального органічного вуглецю у воді. В основу принципу дії аналізатора покладено метод «окислювального спалювання -інфрачервоного аналізу»: каталітичне окислення при температурі $680^{\circ} \mathrm{C}$ з утворенням $\mathrm{CO}_{2}$ і детектування поглиненого ІЧ-випромінювання. Діапазон вимірювань загального вуглецю: 0-25000 мг/дм³. Відтворюваність результатів вимірювань - коефріцієнт варіації CV в межах $1,5 \%$. Значення CV може бути дещо збільшено при малій інтенсивності аналітичних піків.

Адсорбція АПАР шлаковими сорбентами вивчена у статичному режимі протягом 3 діб і в динамічному режимі з примусовим перемішуванням порошкоподібних шлакових адсорбентів протягом 2-4 годин. В якості АПАР обрана натрієва сіль додецилсульфокислоти $\mathrm{C}_{12} \mathrm{H}_{25} \mathrm{OSO}_{3} \mathrm{Na}$. Отримані результати, представлені в таблиці 1.8, доводять можливість протікання адсорбції аніону АПАР на шлаках з від'ємно зарядженою поверхнею. Це свідчить про істотну частку дисперсійної взаємодії в загальному механізмі адсорбції ПАР.

Порівняння ефективності і величини адсорбції АПАР в статичному і динамічному режимах некоректно, тому що розрізняється час адсорбції. Доцільно порівняння швидкостей адсорбції АПАР

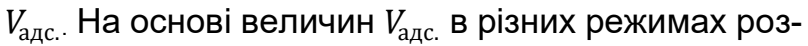
рахований коефіцієнт перерахунку значень швидкості адсорбції з одного режиму на інший

$$
k=\frac{V_{\text {адс.дин. }}: \text { адс.стат. }}{V_{\text {a }}}
$$

для шлаків ПФНК та КР $k=23$ для шлаку НЗФ $k=83$. Шлаки НЗФ і ПФНК мають однаковий мінералогічний склад, тому велика швидкість адсорбції шлаком НЗФ обумовлена більшою його дисперсністю. Розмір частинок для шлаків, мм: НЗФ - < 0,63; ПФНК - $(0,5-1,6)$. Результати наведено у таблиці 8.

Таблиця 8. Кількісні критерії адсорбції шлаковими адсорбентами АПАР із розчину початкової концентрації $C_{0}=0,133$ г/дм ${ }^{3}$ при різних режимах процесу: $C$ - кінцева концентрація АПАР у розчині; $a$ - величина адсорбції; $E$ - ефективність вилучення АПАР; $V_{\text {адс. }}=\left(C_{0}-C\right) / \tau$ - швидкість вилучення АПАР

\begin{tabular}{|c|c|c|c|c|}
\hline $\begin{array}{c}\text { Шлак, режим } \\
\text { адсорбції }\end{array}$ & $C, \frac{\mathrm{r}}{\mathrm{AM}^{3}}$ & $a, \frac{\mathrm{Mr}}{\mathrm{r}}$ & $E, \%$ & $\frac{\substack{V_{\text {адс. }} \\
\text { мг }}}{\text { дм }^{3} \cdot \text { год }}$ \\
\hline КР статичний & 0,110 & 2,3 & 17,3 & 0,32 \\
\hline КР динамічний & 0,118 & 1,5 & 11,3 & 7,5 \\
\hline НЗФ статичний & 0,115 & 0,36 & 13,5 & 0,25 \\
\hline НЗФ динамічний & 0,0914 & 0,832 & 31,3 & 20,8 \\
\hline ПФНК статичний & 0,0815 & 1,03 & 38,7 & 0,72 \\
\hline ПФНК динамічний & 0,0987 & 0,686 & 25,8 & 17,15 \\
\hline
\end{tabular}

Високі значення коефріцієнту перерахунку дозволяють стверджувати, що за час проведення 
адсорбції в динамічному режимі створюються умови наближені до рівноважних. У зв'язку з цим можна побудувати ізотерму адсорбції додецілсульфонату натрію (рис. 2). На ізотермі адсорбції виділяються чотири області. Перша область повільного збільшення величини адсорбції із зростанням концентрації АПАР закінчується при $\mathrm{C}=0,1$ г $/$ дм $^{3}$ і досягненні $\mathrm{a}=0,6 \mathrm{мг} / г$.

Так як іон АПАР і поверхня шлаку заряджені від'ємно, то причиною адсорбції є дисперсійна взаємодія молекул АПАР з поверхнею. Другу область являє собою плато, що закінчується при досягненні рівноважної критичної концентрації міцелоутворення ККМ = 0,16 г/дм³ . Даній ситуації відповідає заповнення всій поверхні шлаку молекулами АПАР і зміна структури адсорбційного шару таким чином, що стає можливою подальша адсорбція АПАР з міцелярних розчинів, чому відповідає третя область. Різке збільшення а може бути викликано декількома причинами: посиленням асоціації одиничних молекул АПАР в адсорбційному шарі за рахунок тяжіння вуглеводневих радикалів молекул; адсорбцією міцел, що існують у розчині при $C$ > ККМ; проявом гідрофобної взаємодії - витіснення вуглеводневих ланцюгів 3 водного розчину.

Протиточно-ступінчата адсорбційна очистка стічних вод від ПАР. Для очистки стічних вод від ПАР на рівні високих концентрацій запропонована раціональна протиточно-ступінчата адсорбційна схема періодичної дії. Пересування води, що очищається і зустрічний рух шлакового адсорбенту в каскаді з трьох адсорберів з відстійниками наведено на рис. 3. Вода, очищена від ПАР до концентрації, що відповідає вихідний для певної ступені каскаду, надходить в наступний адсорбер, де змішується з дозою шлакового адсорбенту масою $m$.

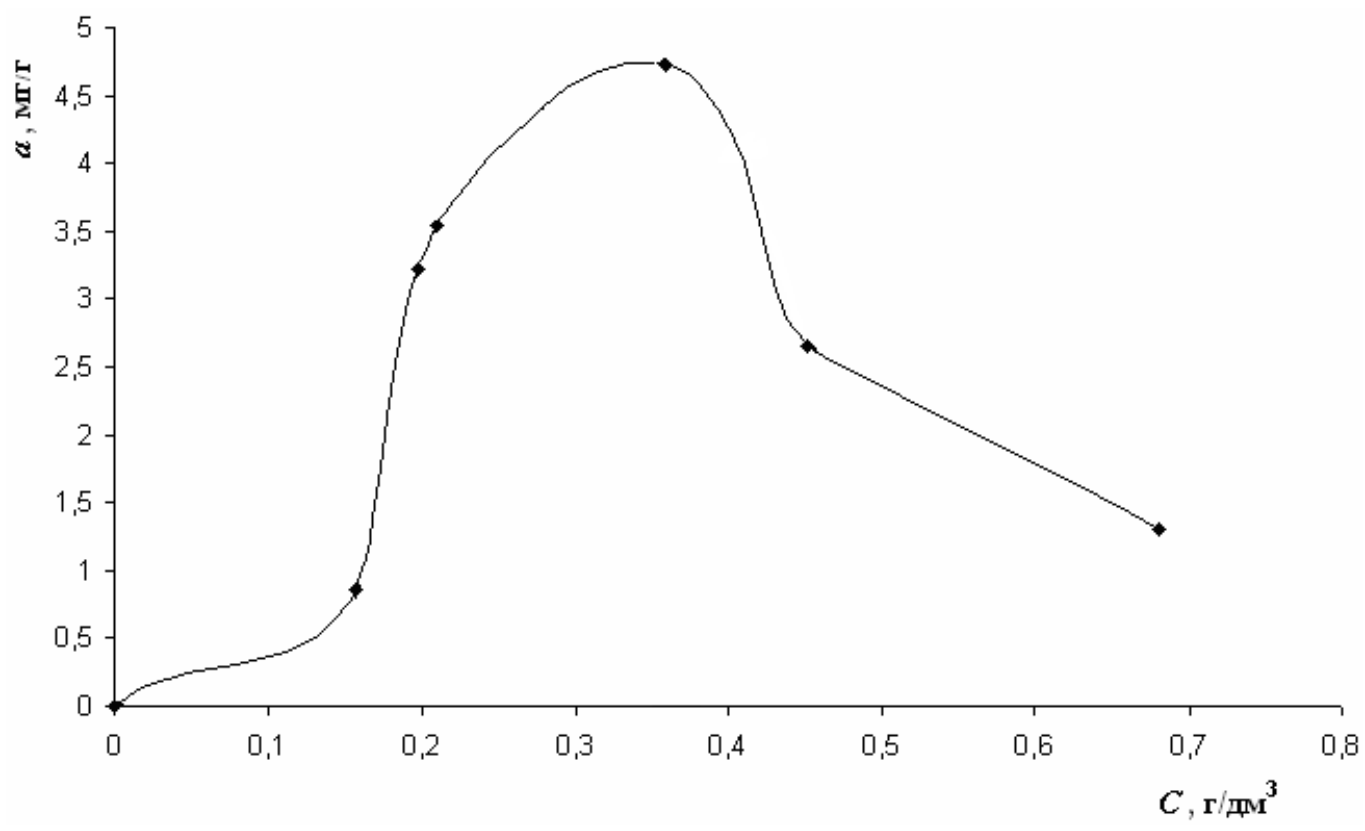

Рис. 2. Ізотерма адсорбції $\mathrm{C}_{12} \mathrm{H}_{25} \mathrm{OSO}_{3} \mathrm{Na}$ шлаком ПФНК. Час динамічної адсорбції 2 години

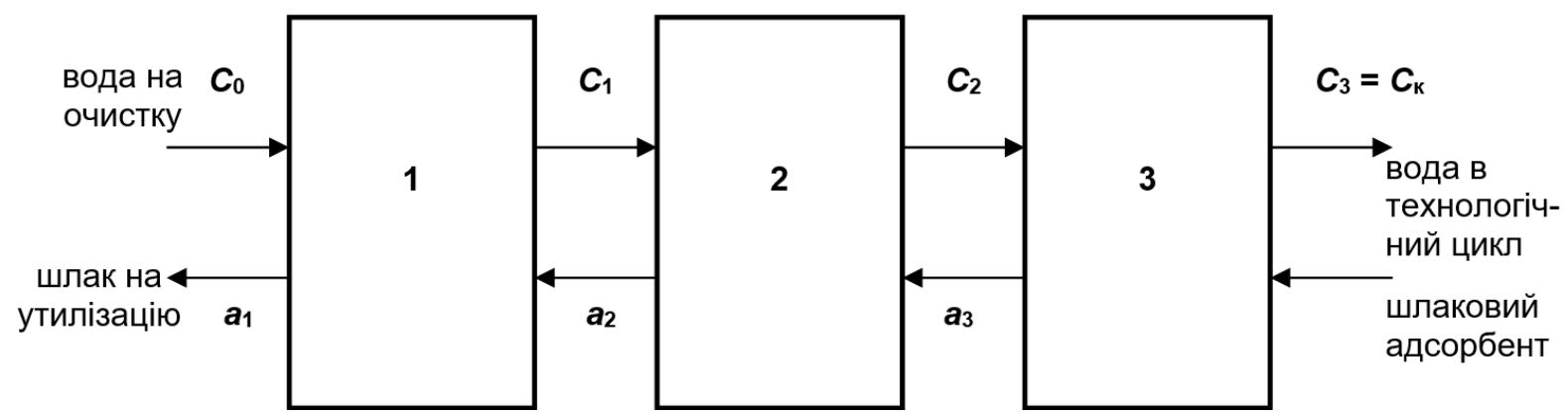

Рис. 3. Схема протиточно-ступінчатої адсорбційної очистки стічних вод від ПАР: (1-3) - адсорбери з відстійниками адсорбційного каскаду; C - концентрації ПАР; а - ємкість адсорбенту на кожній ступені очистки 
Шлак, відділений від очищеної води в певному адсорбері, шламовим насосом переноситься в модуль попередньої ступені, де змішується з водою, що має більш високу концентрацію ПАР. Таким чином, в протиточно-ступінчатій технології очистки доза адсорбенту вичерпує свою ємність, повністю насичуючись ПАР. Свіжа порція шлаку надходить тільки в кінцевий адсорбер. У кожному змішувачі вода перемішується з адсорбентом протягом часу, достатньому для встановлення рівноваги.

Висновки. Використання сучасних фрізико-хімічних методів дослідження дає можливість визначити склад шлаків і прогнозувати їх властивості як технічних матеріалів. Рентгенофазовий аналіз дозволив виявити мінерали шлаків, що знаходяться в кристалічному стані, і визначити структури кристалів мінералів. Виявлено гранулометричні фракції шлаків з підвищеним вмістом алюмосилікатів кальцію і магнію, що проявляють сорбційну активність. На підставі оксидних складів шлаків, їх кристалічної і аморфної частини розрахована масова частка склоподібного компонента, яка становить близько половини маси шлаку ПФНК. Наявність склофрази сприяє до прояву шлаками сорбційної активності. Визначено питомі поверхні шлакових сорбентів. Згідно радіаційним характеристикам, досліджені шлаки відносяться до I класу радіаційної небезпеки. Розроблено спосіб протиточно-ступінчатої адсорбційної очистки промислових стічних вод від ПАР в області високих концентрацій періодичної дії з використанням шлакового сорбенту.

\section{Література}

1. Болдырев А. С. Технический прогресс в промышленности строительных материалов / A.
С. Болдырев, В. И. Добужинский, Я. А. Рекитар. - М.: Стройиздат, 1980. - 399 с.

2. Когановский А. М. Адсорбция органических веществ из воды / А. М. Когановский, Н. А. Клименко, Т. М. Левченко, И. Г. Рода. - Л.: Химия, 1990. - 256 c.

3. Запольський А. К. Фізико-хімічні основи технології очищення стічних вод / А. К. Запольський, Н. А. Мішкова-Клименко, І. М. Астрелін та ін. - К.: Лібра, 2000. - 552 с.

4. СанПиН № 4630-88. Санитарные правила и нормы охраны поверхностных вод от загрязнения.

5. Когановский А. М. Адсорбция и ионный обмен в процессах водоподготовки и очистки сточных вод / А. М. Когановский - К.: Наук. думка, 1983. $-240 \mathrm{c}$

\section{References}

1. Boldyrev, A. S., Dobuzhinskiy, V. I. and Rekitar, Y. A. (1980) Tekhnicheskiy progress $v$ promyshlennosti stroitel'nykh materialov. Moscow: Stroyizdat. p. 399.

2. Koganovskiy, A. M. et al. (1990) Adsorbtsiya organicheskikh veshchestv iz vody. Leningrad: Khimiya. p. 256.

3. Zapol's'kiy, A.K. et al. (2000) Fízikokhímíchní osnovi tekhnologii ochishchennya stíchnikh vod. Kyiv: Líbra. p. 552.

4. SanPiN № 4630-88. Sanitarnyye pravila $i$ normy okhrany poverkhnostnykh vod ot zagryazneniya (1988). USSR. Available at: http://www.cawat er-info.net/bk/improvement-irrigated-agriculture/files /sanpin-4630-88.pdf.

5. Koganovskiy, A. M. (1983) Adsorbtsiya i ionnyy obmen $v$ protsessakh vodopodgotovki i ochistki stochnykh vod. Kyev: Naukova dumka. p 240.

\section{Аннотация}

\section{Использование металлургических шлаков в качестве сорбентов поверхностно-активных веществ}

\section{И.В. Грайворонская, Э.Б. Хоботова, Н.М. Кириенко}

Определены элементный, оксидный, минералогический и радионуклидный состав металлургических шлаков. Установлен класс радиационной опасности исследованных шлаков. Определены удельные поверхности шлаковых сорбентов. Теоретически и экспериментально обоснованы принципы определения сорбционной активности металлургических шлаков. Показана возможность использования шлаков с основным минералом диопсидом в качестве сорбентов для очистки воды. Активность сорбции шлака обусловлена высоким содержанием диопсида в аморфном состоянии. Показана возможность сорбции шлаком органических веществ. По химическому составу и радиационным характеристикам шлак может быть использован в качестве технического материала. Показано проявление сорбционной активности металлургического шлака. Сорбционные свойства обусловлены наличием аморфного состояния вещества. Определена возможность использования 
шлаков при сорбционной обработке вод в технологических циклах. Для очистки сточных вод от поверхностно-активных веществ на уровне высоких концентраций предложена рациональная противоточно-ступенчатая адсорбционная схема периодического действия. Представлены ресурсосберегающие разработки, позволяющие расширить сырьевую базу для производства сорбентов, улучшить экологическую ситуацию регионов за счет предотвращения сброса промышленных сточных вод при внедрении систем оборотного водоснабжения предприятий.

Ключевые слова: металлургический шлак, сорбент, адсорбция, минерал, очистка, сточные воды, поверхностно-активные вещества

\begin{abstract}
The use of metallurgical slag as a sorbent for surfactants

I.V. Hraivoronska, E.B. Khobotova, M.M. Kirienko

The elemental, oxide, mineralogical and radionuclide composition of metallurgical slags is determined. The class of radiation danger of researched industrial waste is carried out. The specific surfaces of slag sorbents were determined. The principles of metallurgical slag fractions sorption activity determination are substantiated theoretically and experimentally. The possibility of the using of slags with the main diopside mineral as sorbents for the water purification has been shown. The slag sorption activity is caused by high content of diopside in the amorphous state. The possibility of slag sorption of the organic substances was shown. According to chemical composition and radiation characteristics slag may be used as technical material. The display of sorptive activity of metallurgical slag is proved. Sorptive properties are caused by the presence of amorphous condition of the substance. The possibility of slag's utilization in water sorption treatment in technological cycles was determined. A rational counterflow-stepped adsorption scheme of periodic action is proposed for sewage treatment at the level of high concentrations of surfactants. The designs with resource saving effect which allow both to extend the raw materials base for the production of sorbents and to improve the environmental situation of the region through the prevention of dumping at the introduction of water recycling enterprises are presented.
\end{abstract}

Keywords: metallurgical slag, sorbent, adsorption, mineral, purification, waste water, surfactants

Бібліографічне посилання/ Bibliography citation: Harvard

Hraivoronska I., Khobotova E., and Kirienko M. (2019). The use of metallurgical slag as a sorbent for surfactants. Engineering of nature management, (3(13), pp. $110-117$.

Подано до редакції / Received: 28.11.2019 